\title{
Inside the Institution of the Prison: A Researcher's Perspective
}

\author{
JANE CARRIGAN \\ Griffith College, Dublin, Ireland
}

Ironically, my memory of first entering a prison, as a novice researcher, is one of brilliant sunshine and blue skies. Access to the largest committal prison in Ireland, during the month of June in 2005, was relatively stress free. I was with a national health organization on a Master's work placement programme, my supervisor was with me and beyond waiting at gates for entry, within what seemed minutes, we were in.

The project we were working on sought to investigate drug policies in prisons from a security and health care perspective. I had a prison officer accompany me at all times and the work itself was interesting and eye-opening. I got to interview prison nurses (who were at the time a relatively new addition to the Irish prison service) and prison officers, and also talk to medical orderlies (prison officers with medical training) who were anxious and concerned about their job conditions. The project taught me some valuable research (and life!) lessons: not everyone welcomes researchers; institutions are curious places with a life and rhythm of their own; and people can always surprise you with their opinions and narratives. Most important of all however, thanks to that project, I got the experience of seeing inside a prison, and from it, a desire to learn more about the people within it. Four years later, my $\mathrm{PhD}$ research, which sought to collate the educational life histories of prisoners attending education classes within the Irish prison system, provided me with the opportunity to undertake research in three prison sites in Ireland. Almost 10 years since I first entered the prison as a naïve researcher, and having reflected on what I've learnt, there are five pieces of advice I would like to offer future prison researchers.

\section{Read as much as you can about prisons and life within prisons}

Foucault (1977) makes the point that prisons, though relatively modern inventions, are so ingrained in our understanding of how a society must function that life without them is probably unimaginable. Until I entered a prison, much of my knowledge of prisons, or as Foucault termed, "complete and austere institutions" (p. 235), had been based on popular culture with films such as The Shawshank Redemption. Goffman (1961) and others, including Christie (2000) and Becker (1963), have argued that in the criminal justice system of a modern society an offender is "symbolically forced outside the normal life of the social group" (p. 192) so that he becomes an outsider, or "other". The idea of the prisoner as 'other' was, in hindsight, already in my consciousness. What startled me most about my time in the prison during that summer of 2005 was how ordinary things quickly became, how I had to adjust to what is an extraordinary situation and how, from my glimpses of prisoners as I made my way through the prison, how very ordinary, rather than 'other', they appeared.

While nothing quite prepares you for prison research, reading descriptions of prison life and prison experiences certainly helps. When I returned to prison research in 2009, this time as a lone Phd student, I found entry to prison more challenging. It involved negotiating with a number of stakeholders from national organisations such as the Irish Prison Service to individual prisons. It took time and effort to secure access, a point which was illustrated in Schlosser's (2008) observation that "often, however, gaining ultimate access to the prison requires significant tenacity and persistence" (p. 1509). The entry procedures were intimidating at first and served to cause anxiety rather than soothe it. The repetition to various prison officers on gate duty of who I was and what I was doing was at times irritating (and sometimes intimidating) although the longer the research lasted in each site, the less this occurred. I thought my experiences were unique to me until I read Marsha Hunt's (1999) wonderful account of teaching creative writing in Mountjoy Prison in Dublin and the difficulties she sometimes encountered with prison 
officers when she tried to get access to her classroom in the prison. Her words resonated strongly with me, provided reassurance that my feelings and experience were not unique, and encouraged me to keep going.

Many other non-academic accounts of prison life helped me too. Later on I discovered an article by Jewkes (2012) who identified an absence of emotion in prison studies in general. She argues that this absence could be because of an academic environment in which the researchers emphasize objectivity and rationality, leading her to state "in informal conversations, all prison researchers will relate stories about moments (or prolonged periods) of empathy, embarrassment, fear, nervousness, dilemma, and so on, but they rarely admit to these feelings in their published narratives" (p. 64). These words also helped and provided a reminder of just how valuable it is to realise that there can be gaps in the academic literature.

\section{Understand prison as a site of contested identity}

Who am I? I'm not sure I can think of a more profound question. Prison, and perhaps all institutions, forces you to confront that question. While a focus on who we are and how we define ourselves is a feature of contemporary life, this focus on identity is intensified within the confines of a total institution where the existence of a consumer culture is limited and people's desire to distinguish themselves through their preference for particular products (e.g. clothes, piercings, cosmetic surgery, physical exercise, to name but a few) may be severely curtailed. Apart from the impact on researchers and staff who work within institutions, it is clear that imprisonment affects inmates' sense of identity. Earlier works about imprisonment by the famous Irish author Brendan Behan (1970) served as an illustration of how prison is a site of contested identity or as Giddens (1984) termed it "a site of struggle and resistance" (p. 154). Behan, for example, tells of his attack on another prisoner, which is presented as an act of self-protection, so as to ultimately avoid his being attacked later on. This need to develop a hard-man persona is not a new development. Another Irish man, Mahon-Smith, who wrote about his experience of imprisonment in the 1940s in Ireland, reported the boasts prisoners would make regarding the violent crimes they had committed and then his surprise on discovering that their offences were as relatively innocuous as begging or small scale theft by deceit.

The criteria for which people are judged on the outside (e.g. clothes, job, material wealth) cease in the prison context to provide effective means for judging other inmates. Yet individuals do strive to maintain their sense of who they are. I was reminded of Alan*, aged 35 at the time of being interviewed for my doctoral research, who was serving a four year sentence for a drugs offence. He maintained his love of keeping busy through his engagement with the prison school and reported spending time writing greeting cards for a fellow prisoner who could not read or write. Alan's belief that this fellow prisoner did not attend school because of a desire not to appear weak to others illustrates the importance given to maintaining a particular image while incarcerated.

Goffman (1961) argued that strong religious and political convictions could help insulate inmates from the effect of an institution on their sense of identity and although, in some specific contexts, imprisonment can be viewed positively (as in a rite of passage or in a political struggle) in general, as Goffman (1961) observes, those who do emerge from confinement within a total institution are often stigmatised. The impact of a total institution on a person is illustrated in Goffman's observations that many inmates will suffer anxiety over release from a total institution.

Nick* was 20 years of age at the time I met him. He told me of how he learnt to read and write in prison and spoke of being incarcerated in various institutions from the age of 11 . He estimated that he had only known about eight months of freedom in all that time. The physical scars on his body bore testament to his violent history. He was an imposing and, in many ways, frightening figure while also someone who seemed so vulnerable too. His observation that people looked at him as if he was a "scumbag" echoed Goffman's (1968) view of the existence of a tendency to view a person with a stigma as "not quite human" (p. 15). He recounted to me that in the prison he was known as a bully and a troublemaker and that to survive in prison "you have to become a bully to not be bullied". Nick's comment illustrated to me the world in which many prisoners live and survive and recognition of this world has implications for researchers, educators and prison staff. Nick was due to be released within a few weeks of my interview with him. Until I met him, I had never thought of being released from prison in a negative way, but Nick was worried. Prison was where his friends were and he understood its rules and could survive there. This young man, angry and vocal with prison staff and some fellow prisoners, and who intimidated me in many respects, doubted whether he would survive outside the prison. I doubted it too.

\section{Appreciate Prison as a Contradictory Space}

Nellis (2002), in an account of how the genre of pris- 
oner autobiographies has developed in a British context in the later part of the twentieth century, has argued that these works serve as a reminder that prison incarcerates individuals with life experiences, rather than simply prisoners who all think and act the same. In prisoners' accounts of life within the prison, the prison itself appears to be a contradictory space, where instances of violence and terror alongside examples of friendships, helpfulness and qualities such as trust can be found. In writing about his imprisonment, Brendan Behan (1970), for example, revealed the threatening atmosphere and the potential for violence among prisoners, while also describing in detail the friendships and support that were also present among them. Jewkes' (2012) assessment that prison research can be emotive and harrowing at times but also positive and life affirming was born witness to in my doctoral research; these two opposite features seemed to illustrate the contradictory space of the prison environment.

As part of my research, I talked to prisoners who were attending the prison school. When I analysed the transcripts later I was amazed at how often the word 'freedom' appeared in prisoners' description of the school and how this concept could be evoked in an institution that was created to deny it. For the men I met, the school represented an escape from the prison regime, a sanctuary of sorts. In interviewing, at one stage of the research, young men who were under the age of 21, three of them reported having learnt to read and write within the environment of the prison. Acts of kindness were in evidence, in and outside of the prison school environment, and often existed in parallel with the harsh reality of often hostile relationships within the prison. One learner spoke of his appreciation of a prison officer, who gave him advice on his work when he was back in the cell and the school had closed for the day. Another man I interviewed spoke of having joined the prison listener scheme in the prison and having undergone a six week training course as part of it. He described how, following his training, he would be 'on call' on certain nights and prison officers would knock on his cell door if another prisoner needed to talk. I also met prison officers who spoke with pride about the prison school and the work that was going on there and others who were openly dismissive of it. I met teachers who were thoroughly inspirational and amazing and some who were not. Prison can definitely challenge stereotypes.

\section{Know the political and social context in which the prison operates}

When I went back to prison research for my $\mathrm{PhD}$ research, only four years had passed since I had first entered a prison site, and yet it was if I was in another world. The political environment had changed in Ireland and conditions for entry into the prison had become much stricter. I was, as the researcher, subjected to airport style security $\mathrm{x}$-ray machines and sniffer dogs upon entry. Dates of when I was entering the prison had to be forwarded to security due to the fact that I was bringing a digital voice recorder into the prison. The presence of the recorder and its similarity in appearance to a mobile phone, the use of which had become a criminal offence within the prison, caused difficulties. What struck me, when I reflect back on this period, was how quickly I became used to such conditions. What seemed strange, extraordinary and almost frightening at the beginning seemed to become normalised and ordinary within a relatively quick period of time.

One of Foucault's (1977) arguments is that the prison is not a standalone entity but rather is influenced and influences wider society. This idea was underscored in Forster's (1998) work and his seemingly contradictory identification of the prison as both powerful and vulnerable. It is clear that prisons do not exist in a vacuum. Munoz (2009), UN Special Rapporteur on the Right to Education, has highlighted the role the media, through its influence on public opinion, has in impacting on prison education, and he argues that this influence, combined with politicians' willingness at times to reflect fears generated regarding crime and punishment has resulted in a reluctance to embed prisoners' right to education in legislation.

Schooling in a prison occupies a precarious position within the prison system due to its reliance on the prison (which as Foucault acknowledged is in itself vulnerable to economic, political and social conditions) and susceptible to outside influences. Irwin (2003) too acknowledges how the prison classroom is embedded within the confines of a prison system and that this context is both influential and limiting in the sense that although the prison is authoritarian and independent within its walls it is also vulnerable to shifts in public policy as the government responds to public feelings about crime and punishment. Researchers need to be aware of the political and social context in which the prison and the prison school operate in and to think about its implications for doing good research.

\section{Make Connections}

This is my last nugget of advice to prison researchers, but by no means least! David and Sutton's (2011) helpful book on research methods had advised budding researchers to seek guidance from experts who have 
knowledge of how particular organisations work and my wise $\mathrm{PhD}$ supervisor had encouraged me to join groups, attend meetings and in many ways simply get out there. I took this advice seriously and I found personal connections made during the proposal, throughout the research process, and even afterwards, to be invaluable to me both as a researcher working on a particular project and also as a person. I learnt and gained so much from meeting people who worked and taught in prisons, who had researched in prisons, or who had worked with other marginalised groups and were prepared to share advice and offer guidance. All of this sustained and supported me during the journey, particularly at inevitable times when doubts crept in, or when decisions did not go as I expected and the end seemed very far away.

I went to conferences and presented at them, meeting more experienced researchers who gave advice and encouragement, and meeting other researchers who were interested in what I was doing and who asked questions that made me think and reflect. I joined relevant associations (such as the Irish Prison Education Association), went to meetings, volunteered for working groups, followed up suggestions on who to contact, and talked to as many relevant people as I could. I was particularly indebted to two prison educators, both of whom had many years of experience teaching in a prison school, and who had both undertaken prison research, for their help in the initial stage of the project and their advice on the most effective means of negotiating access to a prison site.

Research in a prison can be an emotionally draining experience; it can make you reflect on your life, its unfairness at times, and often forces you to address concepts such as freedom and rights. While there are of course moments of happiness and laughter in any research project, there are also moments that make you sad and angry. I found it really helpful in carrying out the research to build in a de-briefing session with another researcher who was undertaking sensitive research at the same time albeit in an institutional, rather than prison setting. We both understood the ethical sensitivities of our work but having the space to reflect and discuss events with a supportive person meant we could in effect help each other.

There are some things that books or journal articles cannot tell you - what your first moment in prison will feel like, who will help you with your research and who will attempt to hinder you, or why the particular institution you're in works in that particular way- but by reading as much as you can, understanding the prison for what it is, knowing the context in which it operates and in particular by making connections with others, you hopefully will be able to negotiate the journey ahead and be in a position to help others too.

* Names are replaced by pseudonyms

\section{Bibliography}

Becker, H. S. (1963). Outsiders: Studies in the sociology of deviance. New York, NY: The Free Press.

Behan, B. (1970). Borstal boy. London: Corgi Books.

Christic, N. (2000). Crime control as industry: Towards gulags, western style ( $3^{\text {rd }} \mathrm{ed}$.). London: Routledge.

David, M. \& Sutton, C. (2011). Social Research (2nd ed). London: Sage.

Foucault, M. (1977). Discipline and punish, the birth of the prison. London: Penguin Books.

Goffman, E. (1961). Asylums: Essays on the social situation of mental patients and other inmates. Harmondsworth: Penguin Books.

Goffman, E. (1968). Stigma: Notes on the management of spoiled identity. London: Penguin.

Hunt, M. (1999). The junkyard: Voices from an Irish prison. Edinburgh: Mainstream.

Jewkes, Y. (2012). Autoethnography and Emotion as Intellectual Resources: Doing Prison Research Differently. Qualitative Inquiry 18(1), 63-77.

Mahon-Smith, W. (1945). I did penal servitude. Dublin: Metropolitan Publishing.

Nellis, M. (2002). Prose and cons: Offender auto/biographies, penal reform and probation training. The Howard Journal, 41(5), 434-468. 
Schlosser, J. (2008). Issues in Interviewing Inmates:

Navigating the Methodological Landmines of

Prison Research. Qualitative Inquiry, 14(8),

$1500-1525$.

Dr. Jane Carrigan recently completed her PhD entitled " Prisoner Learners' Perspectives of Prison Education within the Total Institution of the Prison: A Life History Methodological Approach" through the Educational Disadvantage Centre, St. Patrick's College, Drumcondra. Jane's research interests include educational disadvantage, health inequalities, penal reform and the effect of state policies on the lives of individuals. She is currently Programme Director of Postgraduate Programmes in the Journalism \& Media Faculty in Griffith College Dublin. 